\section{Effect of Time of Planting and Plant Size on the Productivity of 'Festival' and 'Florida Fortuna' Strawberry Plants in a Subtropical Environment}

\author{
Christopher M. Menzel ${ }^{1}$ and Lindsay Smith
}

\begin{abstract}
ADDITIONAL INDEX wORDs. Fragaria $\times$ ananassa, bare-rooted, climate, propagation, yield, cultivar

SUMMARY. The effect of time of planting and plant size on the performance of 'Festival' and 'Florida Fortuna' strawberry (Fragaria $\times$ ananassa) plants was studied at Nambour in southeastern Queensland, Australia, over 2 years. The main objective of the work was to determine whether small plants yielded proportionally less than large plants as planting was delayed. First, bare-rooted transplants of 'Festival' were divided into small (crown diameters ranging from 6 to $10 \mathrm{~mm}$ ) or large plants (10 to $17 \mathrm{~mm}$ ) and planted in late March, mid-April, or late April. Second, transplants of 'Florida Fortuna' were divided into small (5 to $8 \mathrm{~mm}$ ) or large plants (8 to $17 \mathrm{~mm}$ ) and planted in early April, mid-April, or early May. The early planting for each cultivar corresponded with the time that the transplants are first available from commercial strawberry nurseries. Yields were generally greater in plants planted in late March/early April compared with plants planted later. Differences in yield between the small and large plants were consistent across the different times of planting, with the small plants always having lower yields. Small transplants are an issue for the productivity of strawberry fields in this environment whether they are planted early or late. Producers should consider paying a premium for large transplants delivered early in the season.
\end{abstract}

$\mathrm{Y}$ ields of bare-rooted 'Festival' strawberry plants in southeastern Queensland, Australia, were best with a planting in mid-March, with lower yields with earlier or later plantings (Menzel and Smith, 2011). In contrast, large plants with crown diameters ranging from 10 to $17 \mathrm{~mm}$ had higher yields than small plants with crown diameters ranging from 6 to $10 \mathrm{~mm}$. This research did not determine whether small plants yield proportionally less than large plants as planting is delayed after the optimum date.

The work in southeastern Queensland followed previous studies that assessed the productivity of strawberry fields in Florida. Florida has a similar climate to southeastern Queensland, with strawberry fruit produced from December to April which is equivalent to June to October in southeastern Queensland, under similar growing

Department of Agriculture, Fisheries and Forestry, P.O. Box 5083, SCMC, Nambour, Queensland 4560, Australia

We thank Horticulture Australia Limited (HAL), Strawberries Australia, the Queensland Strawberry Growers' Association, Florida Strawberry Growers' Association, Sweets Strawberry Runners, and Red Jewel Nursery for supporting this research.

${ }^{1}$ Corresponding author. E-mail: chris.menzel@daff. qld.gov.au. systems (Peres et al., 2009; Whitaker et al., 2012). Nursery material planted in October in Florida generally provided better yields or returns than material planted in September or November (Albregts and Chandler, 1994; Albregts and Howard, 1974, 1977, 1980; Chandler et al., 1991; Duval et al., 2005; Locascio, 1972).

The size of transplants has been shown to have mixed effects on yield, with experiments conducted in Europe (Bartczak et al., 2010; Schrevens et al., 1989), the United States (Takeda et al., 2004), and South America (Cocco et al., 2011). None of these experiments examined plants of different sizes planted at different times.

The effect of time of planting and plant size on the performance of 'Festival' and 'Florida Fortuna' strawberry plants growing in southeastern
Queensland was studied over 2 years. The 'Festival' transplants were planted in late March, mid-April, or late April, whereas the 'Florida Fortuna' transplants were planted in early April, midApril, or early May. The stock from the nursery was classified as small plants with crowns smaller than $8 \mathrm{~mm}$ ('Florida Fortuna') or smaller than $10 \mathrm{~mm}$ ('Festival'). The large plants had crowns larger than 8 or $10 \mathrm{~mm}$. The early planting for each cultivar corresponded with the time that the transplants are first available from the strawberry nurseries. 'Florida Fortuna' known as 'Florida Radiance' in the United States was developed by Chandler et al. (2009) and has been reported to produce high early season yields and maintain good fruit size. 'Florida Fortuna' has only been grown fairly recently in Australia. In some experiments in Florida, 'Florida Fortuna' has had higher yields than 'Festival' (Chandler et al., 2009; Santos et al., 2009; Whitaker et al., 2012) and has larger fruit at the end of the season during warm weather (Whitaker et al., 2012). These last authors also noted that it has suboptimal growth in the nurseries, including weak petioles that are easily broken. In Florida, 'Festival' is still the main strawberry cultivar produced and accounts for $\approx 60 \%$ of commercial plantings (Whitaker et al., 2011). 'Florida Fortuna' accounts for $\approx 10 \%$ of commercial plantings.

The present experiments were different to the previous research in southeastern Queensland (Menzel and Smith, 2011) in that the treatments involved small and large transplants planted at different times and included 'Florida Fortuna'. It was proposed that the small transplants would yield proportionally less than large transplants as planting was delayed. None of the reports from Florida have investigated these relationships. There have also been no reports on optimum times of planting for 'Florida Fortuna' in the United States. In Australia, transplants

\begin{tabular}{llll}
\hline $\begin{array}{l}\text { Units } \\
\begin{array}{l}\text { To convert U.S. to SI, } \\
\text { multiply by }\end{array}\end{array}$ & U.S. unit & SI unit & $\begin{array}{l}\text { To convert SI to U.S., } \\
\text { multiply by }\end{array}$ \\
\hline 0.3048 & $\mathrm{ft}$ & $\mathrm{m}$ & 3.2808 \\
25.4 & inch(es) & $\mathrm{mm}$ & 0.0394 \\
6.4516 & inch $^{2}$ & $\mathrm{~cm}^{2}$ & 0.1550 \\
28.3495 & $\mathrm{Oz}$ & $\mathrm{g}$ & 0.0353 \\
2.2417 & ton/acre & $\mathrm{t} \cdot \mathrm{ha}^{-1}$ & 0.4461 \\
$\left({ }^{\circ} \mathrm{F}-32\right) \div 1.8$ & ${ }^{\circ} \mathrm{F}$ & ${ }^{\circ} \mathrm{C}$ & $\left(1.8 \times{ }^{\circ} \mathrm{C}\right)+32$
\end{tabular}


of 'Florida Fortuna' are smaller than those of 'Festival' and are not available from the nurseries until April. Transplants of 'Festival' are not available until late March, after the optimum time of planting (Menzel and Smith, 2011).

\section{Materials and methods}

The transplants of 'Festival' and 'Florida Fortuna' were not available at the same time, with the 'Florida Fortuna' plants harvested after the 'Festival' plants as suggested by the owners of the license for these cultivars in Australia. The transplants of 'Florida Fortuna' were also smaller than those of 'Festival', with many of the plants having crowns smaller than $8 \mathrm{~mm}$. Hence, we grew the two cultivars in two experiments.

'Festival'. Bare-rooted transplants of 'Festival' from Stanthorpe in southern Queensland (lat. 28.6 $\mathrm{S}$, long. $152.0^{\circ} \mathrm{E}$, elevation $872 \mathrm{~m}$ ) were planted at Nambour in southeastern Queensland (lat. 26.6 ${ }^{\circ} \mathrm{S}$, long. $152.9^{\circ} \mathrm{E}$, elevation $29 \mathrm{~m}$ ) on 31 Mar. (Day 1), 14 Apr., or 28 Apr. 2010 and on 30 Mar. (Day 1), 13 Apr., or 27 Apr. 2011. The stock was divided into small plants with crowns from 6 to $10 \mathrm{~mm}$ and large plants with crowns from 10 to $17 \mathrm{~mm}$. The strawberry plants were grown as commercial crops as described by Menzel and Toldi (2010). The stock for this experiment was planted after the optimum time of planting (Menzel and Smith, 2011) because growers do not receive transplants of this cultivar until late March.

The diameter of the crown, the number of leaves/plant, and plant dry weight were recorded from 40 plants per treatment at planting. Samples were collected from four individual boxes containing 500 plants. The consignments were selected at random at the packhouse in Stanthorpe. We also collected data on the growth of the other transplants in the consignments, with 40 samples collected at each time of planting. This analysis showed that $48 \%$ of the transplants had crowns smaller than $10 \mathrm{~mm}$ in 2010 , and that $40 \%$ of the transplants had crowns smaller than $10 \mathrm{~mm}$ in 2011 . Data were collected on plant growth every 3 weeks in the field up until early- to midOctober (Day 190 or Day 197). Fruit were harvested every week for an assessment of yield (fresh weight) and fruit fresh weight up until mid-October.
Mature fruit were classified as those that were at least three-quarters colored. Diseased fruit and very small fruit weighing less than $5 \mathrm{~g}$ were discarded. Average seasonal fruit fresh weight is the long-term average value of fruit fresh weight in a treatment pooled across all harvests. No information was collected on the proportion of the harvests in different fruit size categories.

There were two sections in each block, one for recording plant growth and an adjacent one for recording yield. For the growth data, the experiment was laid out in a split-split-plot design, with planting dates in the main plots, plant size in the subplots, and harvest dates in the split-split plots (four blocks $\times$ two plants harvested each time $=$ eight plants per treatment). For the yield and fresh fruit weight data, the experiment was laid out in a split-plot design, with planting dates in the main plots and plant size in the split plots $(4$ blocks $\times 20$ plants in each plot $=80$ plants per treatment). Growth data for the harvests from Day 43 were analyzed by split-split-plot analysis of variance [ANOVA (three planting dates $\times$ two plant sizes $\times$ eight harvests)] using GenStat (version 11; VSN International, Hemel Hempstead, United Kingdom). Data on yield and average seasonal fruit fresh weight were analyzed by split-plot ANOVA (three planting dates $\times$ two plant sizes). The data for each year were analyzed separately. The relationship between yield and plant growth in the six different treatments (three times of planting $\times$ two plant sizes) was assessed by regression analysis each year, using the graphics software SigmaPlot (version 11; Systat, Chicago, IL). A separate analysis was also conducted using the data for 'Florida Fortuna'.

The gross returns from the different treatments were compared using similar analyses as those used to compare yields. The yields ( $\mathrm{g} /$ plant) from each treatment for each month from June to October were multiplied by the average price received for strawberry fruit in the Brisbane Markets from 2003 to 2006 to give the gross returns for each treatment. The average price for fruit received in June, July, August, September, and October used in this analysis was [in Australian dollars (A\$) $(\mathrm{A} \$ 1.00=\mathrm{US} \$ 1.05)] \mathrm{A} \$ 2.28$, $\mathrm{A} \$ 1.82, \mathrm{~A} \$ 1.45, \mathrm{~A} \$ 1.13$, and $\mathrm{A} \$ 1.61$ per 250-g basket, respectively.
'FlORIDA FORTUnA'. Transplants of 'Florida Fortuna' from Stanthorpe were planted at Nambour on $7 \mathrm{Apr}$. (Day 1), 21 Apr., or 5 May 2010 and on 6 Apr. (Day 1), 20 Apr., or 4 May 2011. These planting times were 1 week later than those for 'Festival', with the first time of planting corresponding to when the transplants were first available from the nurseries. This is different to the practice in Florida, where 'Florida Fortuna' is planted before 'Festival' to take advantage of its early yielding characteristics. The stock was divided into small plants with crowns from 5 to $8 \mathrm{~mm}$ and large plants with crowns from 8 to $15 \mathrm{~mm}$ (2010) or with crowns from 8 to $17 \mathrm{~mm}$ (2011). The experimental setup, data collection, and analyses were similar to those used for 'Festival'. The first set of plants was not planted until early April in these experiments because this is the earliest time that 'Florida Fortuna' is available from the nurseries. An analysis of the consignments over the three planting times showed that $49 \%$ of the transplants had crowns smaller than $8 \mathrm{~mm}$ in 2010 , and that $28 \%$ of the transplants had crowns smaller than $8 \mathrm{~mm}$ in 2011 .

Weather data were collected at Nambour (Table 1). It was slightly cooler and drier during the main period of fruit production (June to September) in 2011 than in 2010. Mean and minimum daily temperatures were higher than the long-term averages, whereas total rainfall was lower than the long-term average.

\section{Results}

In the ANOVAs to examine the effect of planting systems on the performance of 'Festival', time of planting and plant size had a significant effect on fruit yield in both years, with $P<0.003$. A similar analysis for 'Florida Fortuna' gave $P<0.002$, except for the effect of plant size in 2011 where $P=$ 0.04 . In all these analyses, the interaction between the time of planting and plant size on yield was not significant ( $P>0.05)$.

'Festival'. There was a mixed effect of planting date on initial plant quality (Table 2). In 2010, initial crown and root dry weights increased as planting was delayed, whereas in 2011 , there was no consistent effect of planting date on transplant quality. The large plants had wider crowns, more leaves/plant, and greater plant 
dry weights than the small plants in both years.

The plants planted in March had higher yields than those planted in April, and the large plants had higher yields than the small plants in both years (Table 3 ). The profitability of the different treatments reflected total yield from June to October, with a strong correlation between returns and yield $[$ returns $(\mathrm{A} S /$ plant $)=0.0062 \times$ yield (g/plant); $\left.R^{2}=0.91\right]$. This analysis also included the data for 'Florida Fortuna'.

In 2010 , there was no significant $(P>0.05)$ effect of time of planting on average seasonal fruit fresh weight $(15.2,15.0$, and $15.5 \mathrm{~g}$ in the three planting treatments), and a small but significant effect of plant size on average seasonal fruit fresh weight $(15.5 \mathrm{~g}$ for small plants and $15.0 \mathrm{~g}$ for large plants) [least significant difference (LSD) $P=0.05$ and 0.4 , respectively]. The response in 2011 was different to the response in 2010. There was a significant effect of time of planting and plant size on average seasonal fruit fresh weight $(16.7,15.5$, and $18.4 \mathrm{~g}$ in the three planting treatments) (LSD $P=0.05$ and 0.9 , respectively) (17.2 $\mathrm{g}$ for small

Table 1. Temperature and rainfall conditions during the experiments on strawberry plants grown at Nambour in southeastern Queensland, Australia, over 2 years. ${ }^{z}$

\begin{tabular}{lcccc}
\hline Yr & $\begin{array}{c}\text { Avg daily } \\
\text { maximum } \\
\operatorname{temp}\left({ }^{\circ} \mathbf{C}\right)^{\mathbf{y}}\end{array}$ & $\begin{array}{c}\text { Avg daily } \\
\text { minimum } \\
\operatorname{temp}\left({ }^{\circ} \mathbf{C}\right)\end{array}$ & $\begin{array}{c}\text { Avg daily } \\
\text { mean } \\
\text { temp }\left({ }^{\circ} \mathbf{C}\right)\end{array}$ & $\begin{array}{c}\text { Total } \\
\text { rainfall } \\
(\mathbf{m m})^{\mathbf{y}}\end{array}$ \\
\hline 2010 & 22.3 & 12.3 & 17.3 & 256 \\
2011 & 22.1 & 10.5 & 16.3 & 236 \\
Long-term mean & 22.5 & 8.8 & 15.7 & 280 \\
\hline
\end{tabular}

${ }^{2}$ Data are average or total values during fruit production from June to September each year. Long-term values are also shown.

${ }^{\mathrm{y}}\left(1.8 \times{ }^{\circ} \mathrm{C}\right)+32={ }^{\circ} \mathrm{F}, 1 \mathrm{~mm}=0.0394$ inch

Table 2. Effect of time of planting and plant size on the diameter of the crown, leaf production, and plant dry weight of 'Festival' strawberry plants in the experiments at Nambour in southeastern Queensland, Australia, in 2010 and 2011.

\begin{tabular}{|c|c|c|c|c|c|c|}
\hline \multirow{2}{*}{$\begin{array}{l}\text { Time of planting } \\
\text { or plant size }\end{array}$} & \multirow{2}{*}{$\begin{array}{c}\text { Crown } \\
\operatorname{diam}(\mathrm{mm})^{\mathrm{z}}\end{array}$} & \multirow{2}{*}{$\begin{array}{c}\text { Leaves } \\
(\text { no. } / \text { plant })^{\mathrm{z}}\end{array}$} & \multicolumn{4}{|c|}{ Dry wt (g/plant $)^{z}$} \\
\hline & & & Leaves & Crown & Roots & Plant \\
\hline \multicolumn{7}{|l|}{2010} \\
\hline Late $\operatorname{March}^{\mathrm{y}}$ & 9.3 & 4.1 & 2.6 & 0.6 & 0.9 & 4.1 \\
\hline Mid-April & 9.3 & 4.6 & 2.0 & 0.7 & 1.4 & 4.1 \\
\hline Late April & 9.4 & 4.6 & 2.2 & 0.9 & 1.6 & 4.7 \\
\hline Maximum $\mathrm{SE}^{\mathrm{x}}$ & 0.3 & 0.2 & 0.2 & 0.1 & 0.1 & 0.3 \\
\hline Small plant ${ }^{\mathrm{w}}$ & 7.3 & 3.4 & 1.1 & 0.4 & 0.7 & 2.2 \\
\hline Large plant ${ }^{\mathrm{w}}$ & 11.4 & 5.5 & 3.5 & 1.1 & 1.9 & 6.5 \\
\hline Maximum SE & 0.2 & 0.1 & 0.1 & 0.1 & 0.1 & 0.2 \\
\hline \multicolumn{7}{|l|}{2011} \\
\hline Late March & 10.2 & 3.5 & 2.2 & 0.6 & 1.0 & 3.8 \\
\hline Mid-April & 10.1 & 4.3 & 2.0 & 0.7 & 1.1 & 3.8 \\
\hline Late April & 10.5 & 3.7 & 2.1 & 0.7 & 0.7 & 3.5 \\
\hline Maximum SE & 0.4 & 0.2 & 0.2 & 0.1 & 0.1 & 0.3 \\
\hline Small plant & 7.6 & 3.0 & 0.8 & 0.3 & 0.4 & 1.5 \\
\hline Large plant & 12.9 & 4.7 & 3.4 & 1.0 & 1.5 & 5.9 \\
\hline Maximum SE & 0.2 & 0.1 & 0.1 & 0.1 & 0.1 & 0.2 \\
\hline
\end{tabular}

${ }^{2}$ Data are the means of 80 or 120 samples per treatment, pooled across the three times of planting or two plant sizes. The differences between the small and the large bare-rooted plants were similar at the three times of planting; $1 \mathrm{~mm}=0.0394$ inch, $1 \mathrm{~g}=0.0353 \mathrm{oz}$.

'The first time of planting corresponded to when the transplants were first available from the nurseries.

${ }^{x}$ Maximum SE from the SES calculated with the means presented in a column.

wThe small plants had crown diameters from 6 to $10 \mathrm{~mm}$, and the large plants had crown diameters from 10 to $17 \mathrm{~mm}$.

plants and $16.5 \mathrm{~g}$ for large plants) (LSD $P=0.05$ and 0.6 , respectively). The general means $( \pm \mathrm{SE})$ pooled across all the treatments were $15.2 \pm 0.2 \mathrm{~g}$ in 2010 and $16.8 \pm 0.3 \mathrm{~g}$ in $201 \mathrm{l}$.

When planted in March, the plants had more leaves per plant, more leaf area per plant, and higher plant dry weights than those planted in April in both years (Table 4). All aspects of growth were greater in the large plants than in the small plants.

'Florida Fortuna'. As in 'Festival', there was a mixed effect of planting date on the quality of the new transplants (Table 5). In 2010, leaf and crown dry weight, and especially root dry weight, were higher in the plants planted in May compared with those planted in April. In contrast, in 2011 , leaf and root dry weight were lower in the plants planted in May compared with those planted in April. All aspects of growth were better in the large transplants compared with that observed in the small transplants in both years.

Yields were higher in the plants planted in early April compared with those planted in mid-April and May (2010) or higher compared with those planted in May (2011) (Table $3)$. Yields were higher in the large transplants than in the small transplants in both years. The gross returns of the different treatments reflected the differences in total yield, as demonstrated previously for 'Festival'.

In 2010, plant size had no significant $(P>0.05)$ effect on average seasonal fruit fresh weight (20.9 $\mathrm{g}$ for small plants and $19.1 \mathrm{~g}$ for large plants). In contrast, the fruit from the second planting $(21.5 \mathrm{~g})$ were larger than those from the third planting (18.7 g), with the fruit from the first planting intermediate (19.9 g) (LSD $P=0.05$ and 1.8 , respectively). The response in 2011 was opposite to the response in 2010 , with plant size affecting fruit size but not time of planting. Average fruit size was $22.8 \mathrm{~g}$ in the small plants and $20.7 \mathrm{~g}$ in the large plants (LSD $P=$ 0.05 and 1.1, respectively). Average fruit size was $21.3,22.0$, and $22.0 \mathrm{~g}$ in the three different planting times. Mean average seasonal fruit fresh weight pooled across all the treatments was $20.0 \pm 0.5 \mathrm{~g}$ in 2010 and $21.8 \pm 0.3 \mathrm{~g}$ in 2011 . The fruit of 'Florida Fortuna' were $\approx 30 \%$ larger than those of 'Festival'. 
In 2010, average plant growth decreased as planting was delayed (Table 6). The only exceptions to this response were crown dry weight, which was only lower in the plants planted in early May, and root dry weight, which was unaffected. In 2011, growth was lower in the plants planted in mid-April and early May compared with that of the plants planted earlier (Table 6). Growth

Table 3. Effect of time of planting and plant size on yield and gross returns in Australian dollars (A\$) (within brackets) in 'Festival' and 'Florida Fortuna' strawberry plants at Nambour in southeastern Queensland, Australia, in 2010 and 2011.

\begin{tabular}{|c|c|c|c|c|}
\hline \multirow[b]{2}{*}{$\begin{array}{l}\text { Time of planting } \\
\text { or plant size }\end{array}$} & \multicolumn{4}{|c|}{ Yield (g/plant) and [return (A\$/plant) $]^{\mathrm{z}}$} \\
\hline & $\begin{array}{c}\text { 'Festival' } \\
2010 \\
\end{array}$ & $\begin{array}{c}\text { 'Festival' } \\
2011 \\
\end{array}$ & $\begin{array}{l}\text { 'Florida } \\
\text { Fortuna' } \\
2010\end{array}$ & $\begin{array}{c}\text { 'Florida } \\
\text { Fortuna' } \\
2011 \\
\end{array}$ \\
\hline Late March or early Aprily & $875(\$ 5.32)$ & $966(\$ 5.74)$ & $827(\$ 5.01)$ & $823(\$ 4.88)$ \\
\hline Mid-April & $689(\$ 3.98)$ & $668(\$ 3.92)$ & $518(\$ 3.08)$ & $749(\$ 4.32)$ \\
\hline Late April or early May & $643(\$ 3.74)$ & $740(\$ 4.19)$ & $478(\$ 2.83)$ & $643(\$ 3.67)$ \\
\hline $\begin{array}{l}\text { Least significant } \\
\quad \text { difference } \\
\quad(\text { LSD })(P=0.05)^{\mathrm{x}}\end{array}$ & $104(\$ 0.59)$ & $100(\$ 0.53)$ & $138(\$ 0.83)$ & $136(\$ 0.84)$ \\
\hline Small plant ${ }^{\mathrm{w}}$ & $664(\$ 3.83)$ & $723(\$ 4.12)$ & $552(\$ 3.22)$ & $704(\$ 3.99)$ \\
\hline Large plant ${ }^{\mathrm{w}}$ & $808(\$ 4.86)$ & $860(\$ 5.13)$ & $662(\$ 4.07)$ & $773(\$ 4.59)$ \\
\hline $\operatorname{LSD}(P=0.05)$ & $65(\$ 0.38)$ & $64(\$ 0.37)$ & $59(\$ 0.35)$ & $36(\$ 0.21)$ \\
\hline 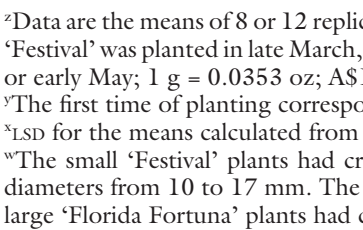 & $\begin{array}{l}\text { tes per treatment, } \\
\text { iid-April, or late A } \\
00=\text { US } \$ 1.05 \text {. } \\
\text { ded to when the t } \\
\text { te analysis of varia }\end{array}$ & $\begin{array}{l}\text { ooled across the th } \\
\text { ril. 'Florida Fortun } \\
\text { ansplants were first } \\
\text { ce. }\end{array}$ & $\begin{array}{l}\text { times of planting } \\
\text { vas planted in earl } \\
\text { ailable from the } 1\end{array}$ & $\begin{array}{l}\text { April, mid-April, } \\
\text { rseries. } \\
\text { lants had crown }\end{array}$ \\
\hline
\end{tabular}

was higher in the large transplants than in the small transplants in both years.

The Relationship BETWEeN YIELD AND PLANT GROWTH. There were strong relationships between yield and average vegetative plant dry weight (leaves, crowns, and roots) in the different cultivars and years (Fig. 1). Yield typically increased as average plant dry weight increased. In 2010, the regressions for the two cultivars had different intercepts and different slopes, whereas in 2011 , the regressions for the two cultivars had different intercepts and similar slopes. When comparing the responses of the cultivars across years, 'Festival' had different slopes and different intercepts, whereas 'Florida Fortuna' had different intercepts and similar slopes. It was slightly cooler and drier in 2011 than in 2010, with lower average plant growth but higher average yield.

\section{Discussion}

These experiments confirm that time of planting and plant size affect the performance of 'Festival' transplants growing in southeastern Queensland (Menzel and Smith, 2011). They

Table 4. Effect of time of planting and plant size on average leaf growth and dry matter production in 'Festival' strawberry plants during the season at Nambour in southeastern Queensland, Australia, in 2010 and 2011.

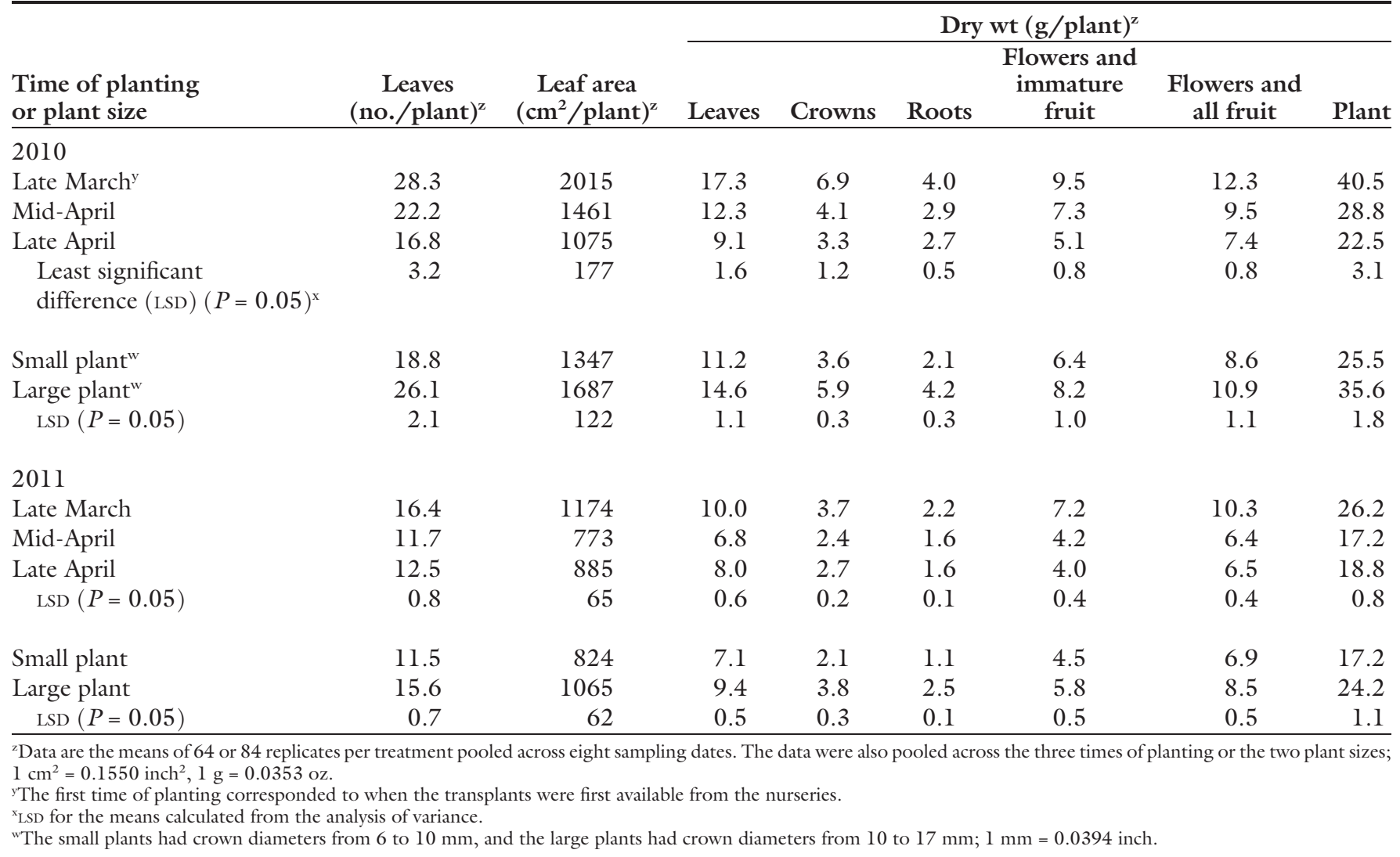


Table 5. Effect of time of planting and plant size on the diameter of the crown, leaf production, and plant dry weight of 'Florida Fortuna' strawberry plants in the experiments at Nambour in southeastern Queensland, Australia, in 2010 and 2011 .

\begin{tabular}{|c|c|c|c|c|c|c|}
\hline \multirow{2}{*}{$\begin{array}{l}\text { Time of planting } \\
\text { or plant size }\end{array}$} & \multirow{2}{*}{$\begin{array}{l}\text { Crown diam } \\
(\mathrm{mm})^{\mathrm{z}}\end{array}$} & \multirow{2}{*}{$\begin{array}{c}\text { Leaves } \\
\left(\text { no. } / \text { plant }^{\mathrm{z}}\right.\end{array}$} & \multicolumn{4}{|c|}{ Dry wt $(g / \text { plant })^{z}$} \\
\hline & & & Leaves & Crown & Roots & Plant \\
\hline \multicolumn{7}{|l|}{2010} \\
\hline Early Aprily & 7.9 & 4.3 & 1.6 & 0.5 & 0.8 & 2.9 \\
\hline Mid-April & 7.7 & 4.1 & 1.6 & 0.5 & 0.7 & 2.8 \\
\hline Early May & 7.7 & 4.9 & 1.8 & 0.8 & 1.6 & 4.2 \\
\hline Maximum $\mathrm{SE}^{\mathrm{x}}$ & 0.3 & 0.1 & 0.1 & 0.1 & 0.1 & 0.3 \\
\hline Small plant ${ }^{\mathrm{w}}$ & 5.9 & 3.9 & 0.8 & 0.3 & 0.5 & 1.6 \\
\hline Large plant ${ }^{\mathrm{w}}$ & 9.6 & 5.0 & 2.5 & 0.9 & 1.5 & 4.9 \\
\hline Maximum SE & 0.1 & 0.1 & 0.1 & 0.1 & 0.1 & 0.2 \\
\hline \multicolumn{7}{|l|}{2011} \\
\hline Early April & 8.5 & 3.7 & 1.6 & 0.5 & 0.7 & 2.8 \\
\hline Mid-April & 8.6 & 3.5 & 1.3 & 0.6 & 0.7 & 2.6 \\
\hline Early May & 8.0 & 3.1 & 0.9 & 0.5 & 0.5 & 1.8 \\
\hline Maximum SE & 0.3 & 0.1 & 0.1 & 0.1 & 0.1 & 0.2 \\
\hline Small plant & 6.5 & 3.0 & 0.7 & 0.3 & 0.3 & 1.3 \\
\hline Large plant & 10.6 & 4.0 & 2.1 & 0.8 & 1.1 & 4.0 \\
\hline Maximum SE & 0.2 & 0.1 & 0.1 & 0.1 & 0.1 & 0.1 \\
\hline
\end{tabular}

${ }^{2}$ Data are the means of 80 or 120 samples per treatment, pooled across the three times of planting or the two plant sizes. The differences between the small and the large bare-rooted plants were similar at the three times of planting; $1 \mathrm{~mm}=0.0394$ inch, $1 \mathrm{~g}=0.0353 \mathrm{oz}$.

y The first time of planting corresponded to when the transplants were first available from the nurseries.

${ }^{x}$ Maximum SE from the SES calculated with the means presented in a column.

whe small plants had crown diameters from 5 to $8 \mathrm{~mm}$, and the large plants had crown diameters from 8 to $17 \mathrm{~mm}$. also demonstrate that 'Florida Fortuna' transplants show a similar response. Yield generally decreased as planting was delayed after the first time that the plants were available from the nurseries. Yield was also lower in small transplants than in large transplants, with a similar response as planting was delayed.

Relative PRODUCTIVITY OF THE TWO CULTIVARs. The yield of 'Festival' was higher than that of 'Florida Fortuna' in 9 of 10 comparisons. The average productivity of 'Festival' was $\approx 15 \%$ higher, reflecting the larger nursery material and the greater plant growth during the production season. The transplants of 'Festival' were also planted I week earlier than the transplants of 'Florida Fortuna'. The response recorded in southeastern Queensland was different to the response recorded in Florida (Chandler et al., 2009; Santos et al., 2009; Whitaker et al., 2012). In these experiments, 'Florida Fortuna' had higher yields than 'Festival' in two of five cases and similar yields in three of five cases. In this area, 'Florida Fortuna' is often planted earlier than 'Festival' to take advantage of its early productivity.

Table 6. Effect of time of planting and plant size on average leaf growth and dry matter production in 'Florida Fortuna' strawberry plants during the season at Nambour in southeastern Queensland, Australia, in 2010 and 2011.

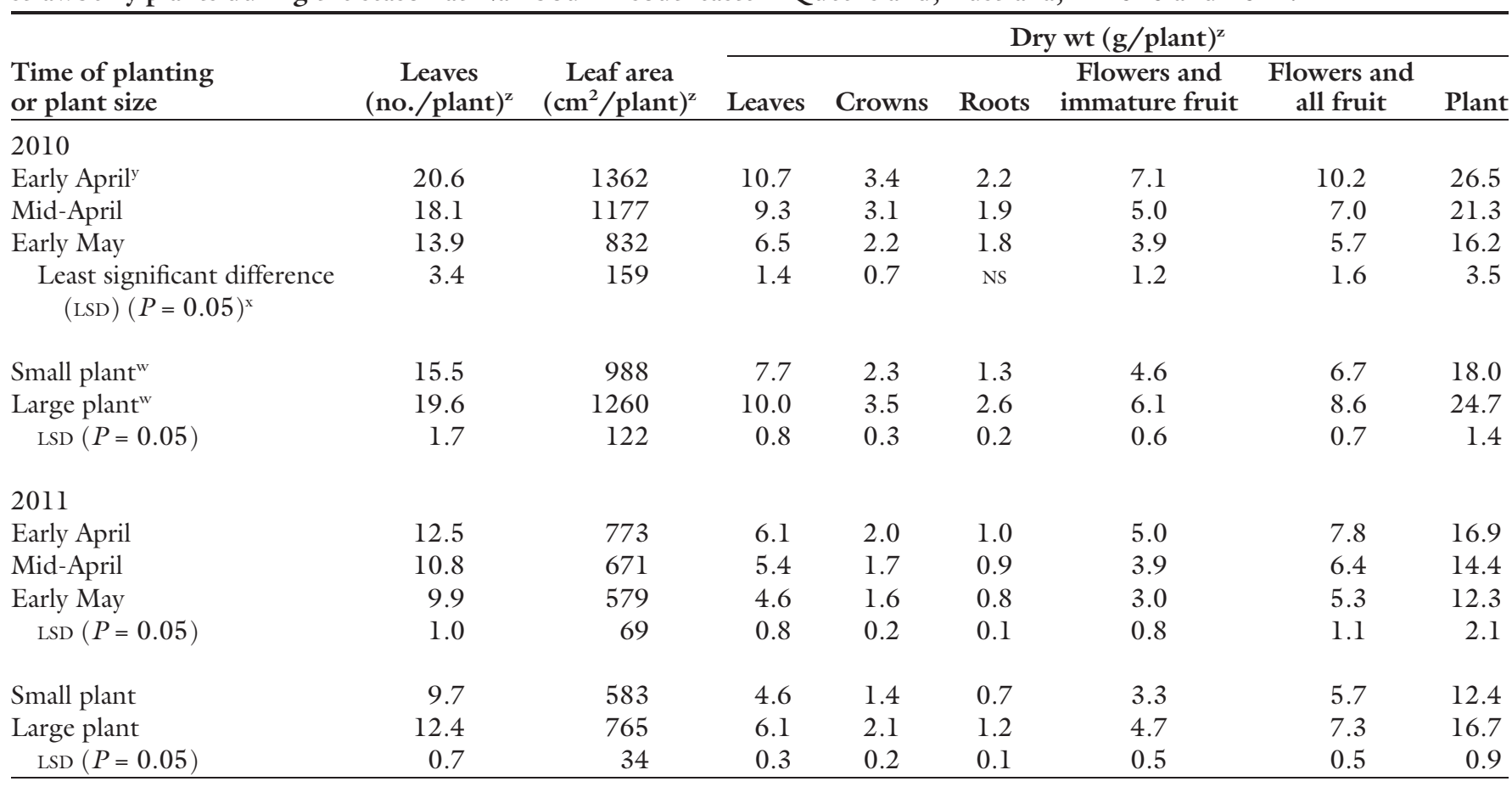

${ }^{2}$ Data are the means of 64 or 84 replicates per treatment pooled across eight sampling dates. The data were also pooled across the three times of planting or the two plant sizes; $1 \mathrm{~cm}^{2}=0.1550$ inch $^{2}, \mathrm{lg}=0.0353 \mathrm{oz}$.

${ }^{y}$ The first time of planting corresponded to when the transplants were first available from the nurseries.

'LSD for the means calculated from the analysis of variance; NS = not significant at $P>0.05$.

w The small plants had crown diameters from 5 to $8 \mathrm{~mm}$, and the large plants had crown diameters from 8 to $17 \mathrm{~mm} ; 1 \mathrm{~mm}=0.0394$ inch. 


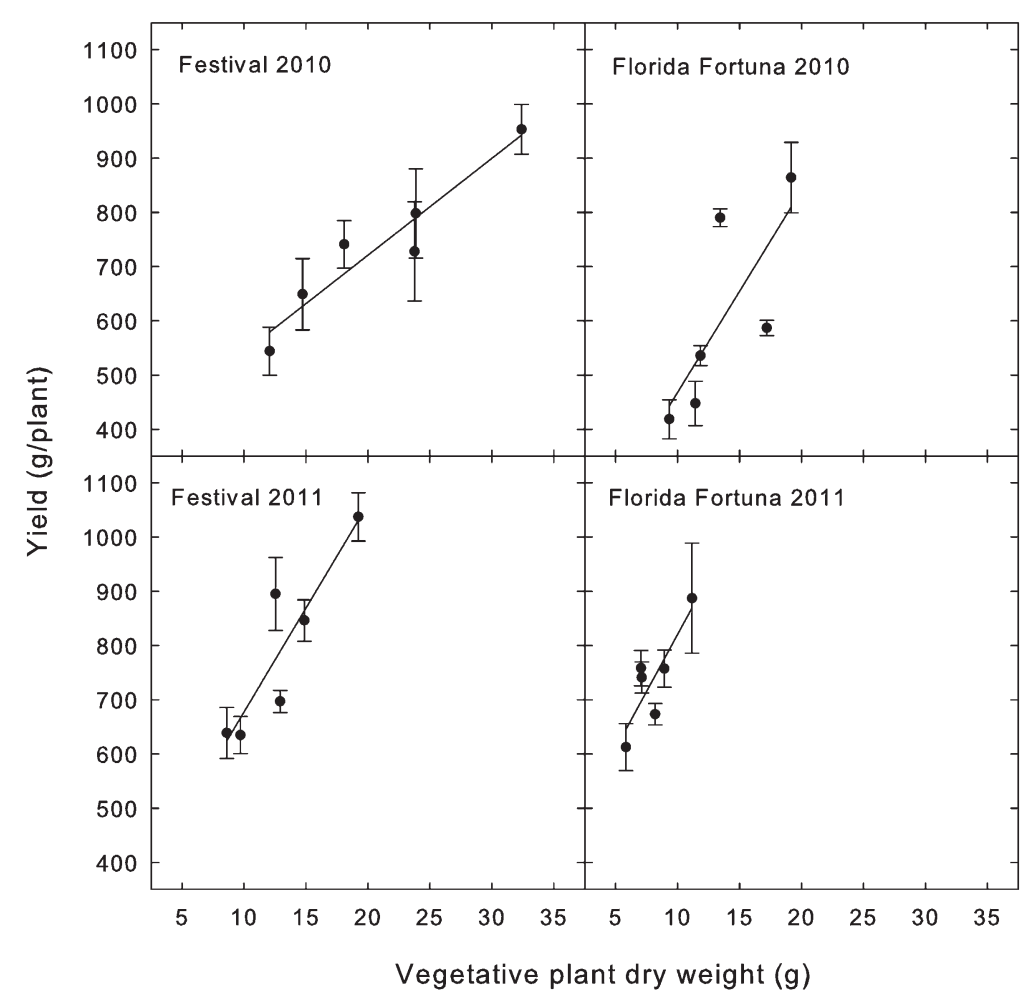

Fig. 1. Relationship between yield and average seasonal vegetative plant dry weight (leaves, crowns, and roots) in 'Festival' and 'Florida Fortuna' strawberry plants grown at Nambour in southeastern Queensland, Australia, in 2010 and 2011. 'Festival' was planted in late March, mid-April, or in late April, whereas 'Florida Fortuna' was planted in early April, mid-April, or in early May. The first time of planting corresponded to when the transplants were first available from the nurseries. The small 'Festival' plants had crown diameters from 6 to $10 \mathrm{~mm}$, and the large 'Festival' plants had crown diameters from 10 to $17 \mathrm{~mm}(1 \mathrm{~mm}=\mathbf{0 . 0 3 9 4}$ inch). The small 'Florida Fortuna' plants had crown diameters from 5 to $8 \mathrm{~mm}$, and the large 'Florida Fortuna' plants had crown diameters from 8 to $17 \mathrm{~mm}$. Data are the means of four replicates per treatment $(N=6)$. For 'Festival' in 2010: yield $=364+$ $17.9 \times$ dry weight $\left(R^{2}=0.89\right)$. For 'Florida Fortuna' in 2010: yield $=96+37.2 \times$ dry weight $\left(R^{2}=0.48\right)$. For 'Festival in 2011 : yield $=294+38.3 \times$ dry weight $\left(R^{2}=\right.$ $0.77)$. For 'Florida Fortuna' in 2011 : yield $=400+42.0 \times$ dry weight $\left(R^{2}=0.64\right)$. Bars show SES.

EFFECT OF TIME OF PLANTING ON GROWTH AND YIELD. There was no consistent effect of time of planting on the dry weight of the new transplants. Samples were collected from only four boxes of 500 plants at each planting time. The quality of transplants can vary greatly with location within the nursery and also with the sorting and grading in the packhouse. Menzel and Smith (2011) showed that there were small differences in the size of 'Festival' transplants planted from late March/early April to late April/ early May at Stanthorpe. In those experiments, the transplants planted in early March were smaller ( $2.5 \mathrm{~g} /$ plant $)$ than those planted later ( 3.2 to $3.7 \mathrm{~g}$ / plant). The effect of planting date on the quality of the transplants probably varies with season and growing conditions. In warm growing conditions, there can be a reduction in average plant size because of overcrowding in the nursery beds at the end of the growing season. There is always a tradeoff between nursery production (number of transplants per unit area of cropping) and the average quality of the transplants (size of the crowns, roots, etc.).

Yield was higher in the first planting than in the second planting in three of four cases and higher in the first planting than in the third planting in four of four cases. In the previous experiment, the best yield was achieved for stock planted in midMarch (Menzel and Smith, 2011), although this is before 'Festival' is generally available. Transplants of 'Florida Fortuna' are not available until early April, and our results showed that delaying planting after this time reduces yield of this cultivar in southeastern Queensland.

Duval et al. (2005) found that transplants of 'Sweet Charlie' and 'Camarosa' planted in early October (equivalent to early April in southeastern Queensland) in Florida over 2 years generally had higher yields in December than transplants planted in late October. Production after December was also influenced by the time of planting, although the effect was not consistent across years or cultivars. Hassell et al. (2006) indicated that average yields of 'Bish', 'Camarosa', 'Chandler', and 'Gaviota' over 3 years in South Carolina were highest with a planting on 20 Oct. $\left(37.8 \mathrm{t} \cdot \mathrm{ha}^{-1}\right)$, intermediate with a planting on 10 Oct. (33.2 $\left.\mathrm{t} \cdot \mathrm{ha}^{-1}\right)$, and lower with a planting on 30 Oct. $\left(30.7 \mathrm{t}^{-h a^{-1}}\right)$.

EFFECT OF PLANT SIZE ON GROWTH AND YIELD. The large transplants were about three times the size of the small transplants at the time of planting. This is consistent with the previous study in southeastern Queensland when the plants were obtained from nurseries in southern Queensland and from nurseries in Victoria and Tasmania in southern Australia (Menzel and Smith, 2011).

Yields were greater in the large transplants than in the small transplants in four of four cases. Overall, the differences between the two groups of plants were greater in 2010 than in 2011, when it was slightly warmer and wetter. In the earlier experiment at Nambour over 3 years, large transplants had $17 \%$ higher yields than small transplants. We recorded a similar difference in average productivity between the two groups of plants in the current experiments.

Bartczak et al. (2010) found a strong correlation between yield and the fresh weight of 'Honeoye' and 'Elsanta' plants at planting $\left(R^{2}=0.64\right)$ in Poland. There were poorer correlations between yield and the numbers of crowns or roots/plant or the length of roots/plant $\left(R^{2}=0.20\right.$ to 0.49). Takeda et al. (2004) conducted similar experiments with 'Chandler' strawberry plants in the eastern United States. The weight of the different transplants varied from 0.9 (very 
light) to $9.9 \mathrm{~g} /$ plant (very heavy), with the larger plants yielding 10\% more than the smaller plants. Cocco et al. (2011) studied the effect of plant size on the performance of 'Arazá' strawberry plants in Brazil using both barerooted (crowns from 3 to $8 \mathrm{~mm}$ or larger) and containerized plants (crowns from 2 to $7 \mathrm{~mm}$ ). Plant size had at best a small effect on yield. Schrevens et al. (1989) conducted similar work in greenhouses in Belgium and reported a mixed effect of initial plant size on productivity over two seasons.

None of the previous research in Queensland and elsewhere determined whether the difference between the small and large plants was greater in later plantings. We found that the small plants did not yield proportionally less as planting was delayed. It is apparent that the lower temperatures that occurred as planting was delayed affecting the small and large plants in a similar way. These results suggest that small plants are an issue for productivity in this environment whenever they are planted. Average gross income was A\$3.79 \pm 0.20 per plant for the small transplants and $\mathrm{A} \$ 4.66 \pm 0.23$ per plant for the large transplants. Average gross income was A\$5.24 $\pm 0.19, \mathrm{~A} \$ 3.83 \pm$ 0.27 , and $A \$ 3.61 \pm 0.28$ per plant for the first, second, and third planting, respectively. In these experiments, on average $\approx 80 \%$ of the crop was produced from August to October when prices for the fruit are relatively low. This pattern of cropping is similar to the response recorded for 'Sweet Charlie' in Florida, with the bulk of the crop produced toward the end of the growing season (MacKenzie et al., 2003).

Plant growth. Plant growth generally decreased as planting was delayed, with a greater response in the first year than in the second year, under slightly warmer and wetter conditions. Growth was also less in the small transplants than in the large transplants. Average growth in the 'Florida Fortuna' plants was two-thirds of that in the 'Festival' plants, and average growth in the second year was about two-thirds of that in the first year. These differences in growth were used to explore the relationship between yield and vegetative growth. There were strong relationships between yield and average seasonal vegetative plant dry weight (leaves, crowns, and roots). Yield increased as plant dry weight increased, with different relationships across the different years and cultivars. Average yields were higher in 2011 than in 2010 , but average plant growth was lower. It was slightly cooler and drier during fruit production in the second year compared with conditions in the first year.

Shaw (1993) found that yield was correlated with the diameter of the plant canopy at various times during the season in hundreds of strawberry genotypes from 20 families growing at two sites in California. However, at other times there was no link between productivity and growth, with the plants growing at the expense of the flowers and fruit. He concluded that overall, sustained productivity was dependent on adequate growth during spring and early summer. Our data suggest that plant growth affects productivity in southeastern Queensland.

Transplants of 'Festival' and 'Florida Fortuna' had lower yields when they were planted after late March or after early April in southeastern Queensland, suggesting that they should be planted when they first become available to commercial producers. Differences in yield between small and large transplants were consistent across different times of planting, with the small plants always having lower yields than the large plants. Producers should consider paying a premium for large transplants delivered early in the season.

\section{Literature cited}

Albregts, E.E. and C.K. Chandler. 1994. Effect of transplant chilling and planting date on fruiting response of 4 strawberry clones. Proc. Florida State Hort. Soc. 107:323-325.

Albregts, E.E. and C.M. Howard. 1974. Effect of planting date, plant chilling, and plant sources on 'Tioga' strawberry growth and fruiting response. Proc. Florida State Hort. Soc. 87:187-192.

Albregts, E.E. and C.M. Howard. 1977. Effect of planting date and pre-plant chilling on strawberry fruit production. Proc. Florida State Hort. Soc. 90:278280.

Albregts, E.E. and C.M. Howard. 1980. Effect of pre-plant transplant chilling and planting date on the growth and fruiting response of 'Dover' strawberry. Proc. Florida State Hort. Soc. 93:239241.

Bartczak, M., J. Lisiecka, and M. Knaflewski. 2010. Correlation between selected parameters of planting material and strawberry yield. Folia Hort. 22:9-12.

Chandler, C.K., E.E. Albregts, and C.M. Howard. 1991. Planting date affects early season strawberry production in west central Florida. Proc. Florida State Hort. Soc. 104:227-228.

Chandler, C.K., B.M. Santos, N.A. Peres, and C. Jouquand. 2009. 'Florida Radiance' strawberry. HortScience 44:17691770.

Cocco, C., J.L. Andriolo, F.L. Cardosa, L. Erpen, and O.J. Schmitt. 2011. Crown size and transplant type on the strawberry yield. Scientia Agr. 68:489-493.

Duval, J.R., C.K. Chandler, and E. Golden. 2005. Planting date affects early season fruit yield of strawberry in a subtropical environment. J. Amer. Pomol. Soc. 59:7-12.

Hassell, R.L., T.L. Phillips, R.J. Dufault, T.A. Hale, and J.R. Ballington. 2006. Fall transplanting affects strawberry cultivar performance in South Carolina. Intl. J. Fruit Sci. 6:73-85.

Locascio, S.J. 1972. Influence of planting date and pre-plant chilling on yield of 'Tioga' strawberries. Proc. Florida State Hort. Soc. 85:110-113.

MacKenzie, S.J., C.I. Xiao, J.C. Mertely, C.K. Chandler, F.G. Martin, and D.E. Legard. 2003. Uniformity of strawberry yield and incidence of botrytis fruit rot in an annual production system. Plant Dis. 87:991-998.

Menzel, C.M. and L. Smith. 2011. Effect of time of planting, plant size, and nurserygrowing environment on the performance of 'Festival' strawberry in a subtropical environment. HortTechnology 21:5666.

Menzel, C.M. and A. Toldi. 2010. An evaluation of containerized plants for strawberries growing in a subtropical environment. HortTechnology 20:786793.

Peres, N.A., J.F. Price, W.M. Stall, C.K. Chandler, S.M. Olson, T.G. Taylor, E.H. Simonne, and B.M. Santos. 2009. Strawberry production in Florida, p. 259-268. In: S.M. Olson and E.H. Simonne (eds.). Vegetable production handbook for Florida 2009-2010. Vance Publishing, Lenexa, KS.

Santos, B.M., C.K. Chandler, M. RamírezSánchez, and T.P. Salamé. 2009. Evaluation 
of strawberry cultivars in Florida. Intl. J. Fruit Sci. 9:419-424.

Schrevens, E., D. Lambert, and L. Lettani. 1989. Intensive hydroponical cropping system for strawberries in greenhouses. Acta Hort. 265:275-282.

Shaw, D.V. 1993. Genetic correlations between vegetative growth traits and productivity at different with-in season intervals for strawberries (Fragaria ×ananassa). Theor. Appl. Genet. 85:1001-1009.

Takeda, F., S.C. Hokanson, and J.M. Enns. 2004. Influence of daughter plant weight and position on strawberry transplant production and field performance in annual plasticulture. HortScience 39:1592-1595.

Whitaker, V.M., C.K. Chandler, B.M. Santos, M.C.N. Nunes, A. Plotto, and
C.A. Sims. 2012. Winterstar ${ }^{\mathrm{TM}}$ ('FL 05-107') strawberry. HortScience 47:296-298.

Whitaker, V.M., T. Hasing, C.K. Chandler, A. Plotto, and E. Baldwin. 2011. Historical trends in strawberry fruit quality revealed by a trial of University of Florida cultivars and advanced selections. HortScience 46:553-557. 